\title{
Wizer.me and Socrative as innovative teaching method tools: Integrating TPACK and Social Learning Theory
}

\author{
Narentheren Kaliappen', Wan Nurisma Ayu Ismail ${ }^{2}$, Ahmad Bashawir Abdul Ghani ${ }^{3}$, Dwi Sulisworo ${ }^{4}$ \\ ${ }^{1,2,3}$ School of International Studies, College of Law, Government \& International Studies, Universiti Utara Malaysia, \\ Malaysia \\ ${ }^{4}$ Department of Educational Management, Universitas Ahmad Dahlan, Yogyakarta, Indonesia
}

\begin{tabular}{l} 
Article Info \\
\hline Article history: \\
Received Feb 15, 2021 \\
Revised Jul 7, 2021 \\
Accepted Jul 21, 2021 \\
\hline
\end{tabular}

\section{Keywords:}

Activity based teaching Cross-cultural management Social learning theory Socrative TPACK

Wizer.me

\begin{abstract}
The purpose of this paper is to share a lecturer's viewpoint on using Wizer.me and Socrative applications as an innovative teaching method integrating TPACK and Social Learning Theory (SLT) at higher education. The applications were used to teach 44 undergraduate students who registered for Cross-Cultural Management course at Universiti Utara Malaysia (UUM). At first, the lecturer used Wizer.me before the class starts and requesting the students to answer several questions before coming to the class. After completing each chapter, the students requested to answer some questions using Socrative application to test their understanding level. The research revealed that at the beginning of the semester, the students not aware of these two applications. However, at the end of the semester, every student familiar with these applications and overall provided positive feedback on the usage of Wizer.me and Socrative application in the teaching and learning process. This study used IntenCheck sentiment analysis software to evaluate the students' feedback. Student's opinion on using Wizer.me and Socrative application as an innovative teaching method not explored before at UUM. Therefore, this viewpoint could provide useful insight for university lecturers to use these applications in their teaching and learning process.
\end{abstract}

This is an open access article under the CC BY-SA license.

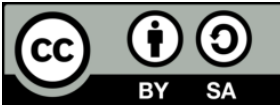

\section{Corresponding Author:}

Narentheren Kaliappen

School of International Studies

College of Law, Government \& International Studies

Universiti Utara Malaysia, Malaysia

Email: narentheren@uum.edu.my

\section{INTRODUCTION}

One of the main goals of today's tertiary education is to produce global graduates ready to compete and face the challenges generated by the technological growth of the Industrial Revolution 4.0, which impacts employment by developing new knowledge and skill needed [1], [2]. Thus, the student experience at higher education institutions should allow every student to learn innovatively, achieve their full potential, and develop skills that will help them succeed in the future. So, what is innovative teaching at university, and what shape does it come in? Innovation has been recognized as the gateway to technological progress and improvements in social and cultural standards for higher education institutions [3]. Educational institutions must be resilient to change and continually develop their practices and delivery methods [4], [5].

One of the main competencies for sustainable development is innovation. An essential and significant component of modern sustainable education should be innovative thinking and creative problemsolving. In the sense of education, creativity always lies in the area of teaching [6], [7]. It can take the form 
of using different approaches and new materials, pedagogy, or curricula [8]-[10]. Innovation in teaching was understood and practiced in different ways. Technology is a common factor and used for the delivery of new methods of teaching as a support mechanism [11]-[13]. Before, describe the teaching method, this paper would like to explain about the Cross-Cultural Management (CCM) course.

CCM course is intended to provide prospective foreign and global managers and business negotiators with the basic knowledge of cross-cultural management. It also offers a practical overview of cross-cultural management problems and concerns that students need to consider employing workers in multinational corporations. The development of essential soft skills such as writing, communication, interpretation, critical thinking, and intercultural and cross-cultural skills to collaborate with collaborators, business partners, and customers from different cultures will be emphasized. The students will define the fundamental concepts, theories, and cross-cultural management problems and their effect on the international business, explain the cultural factors and impacts of global governance and results, examine cultural challenges at work and evaluate in an international context the related concepts of cross-cultural situations.

Based on the above explanation, it is concluded that this CCM is content and theory-based course. The teacher has taught this CCM course for two semesters. Based on the class observation, most students were passive and disengaged in the teaching and learning process. This let the researchers' motivation down. The teacher also had a chance to interview a few students repeating this course as they failed in previous semesters. These students were asked why they failed the CCM course. They mentioned that they do not understand what the lecturer taught in class. Some even said that the lecturer just read the slides. Some said they even do not know how to answer the questions in exams. They have never exposed to questions and answers activity in class. Very much teacher-centric! said some students. From this, it can be concluded that the problem is in the delivery method.

These answers triggered to develop something that will encourage students to be active and engaged in learning CCM. The approaches focused on student learning may significantly improve students' learning, motivation, and thinking skills. The teacher has taken activity-based learning for a successful student-teacher relationship to make student-centered learning possible. Active learning enables students to ask, to discover, to experiment, to collaborate and to enjoy the fun of learning. Teachers' role changes from knowledgebuilding to inspiration with this technique [14]-[16]. Therefore, this research's problem is the low learning interaction affecting the students' learning performance in CCM course. This condition due to the lack of teaching and learning methods. This research aim is to conduct fruitful learning using Wizer.me and Socrative application to encounter this problem.

\section{LITERATURE REVIEW}

\subsection{Wizer.me}

Wizer.me is online software and the basic feature is free to download and used by the academics. The Wizer.me worksheet builder compliments teachers' experience and creativity by allowing quick creation of a wide variety of question types: open questions, multiple-choice, matching pairs, fill in the blank, fill on an image and tables [17].

Wizer.me worksheets are visually enticing and inspire students to learn more and spend more time carefully engaging. The worksheets of Wizer.me are magnificent, and teachers can choose from a range of backgrounds and themes. Wizer.me will allow me to add rich media to the mixed worksheet (video, audio, images). Videos can captivate the mind to learn or practice new skills and fancy creative tasks. Furthermore, Wizer.me saves time with automatic checking \& grading or review one by one to give more personal feedback. User/teacher could do personalized teaching and learning in the class. Teacher could see the students enjoy doing these activities in class every time.

\subsection{Socrative application}

Apart from this Wizer.me software, Socrative application was also used to give some reflection questions to get feedback from the students. Socrative is a cloud-based student response system, and it allows creating simple quizzes that students can take quickly on their smartphones. There is also a gaming element: the "Space Race" feature can set up a quiz so that teams of students can compete against one another to launch rockets into space. Besides, the teacher can set whether the correct answer to the given questions is displayed on the app they are using, or only on the front of the teaching room screen [18], [19]. This Socrative application helped teacher to make personalize teaching based on the students' answers. The teacher could monitor every student's work and give instant feedback. 


\subsection{TPACK Model as a pedagogical framework for innovative teaching method}

The TPACK paradigm integrates three information areas of technology, content and pedagogy working together in order to improve students' motivation and accessibility to content. One such model has potential and relevance to today's Higher Education environment, which has recently gained significant visibility [20], [21]. The subject matter is defined in the material. Pedagogy strives to find the best way to convey this knowledge, whether through direct guidance, research, discussion, modelling, adaptive learning, or community methods.

Technology tries to find the best tools to make content more accessible while supporting pedagogy [22], [23]. The digital worksheet created by Wizer.me and Socrative application for this research are fundamental in reaching the learning outcomes for CCM. The TPACK pedagogical model represents the perfect overlap of content, technology and learning modes to deliver and attain the desired outcomes. In this research, content is Cross-Cultural Management; technologies are Wizer.me and Socrative (Digital worksheet) and pedagogy is activity-based teaching and learning.

\section{RESEARCH METHOD}

This study used a classroom action research approach. At the beginning of the lecture, students' perception of using a digital worksheet and their awareness of Wizer.me and the Socrative application was measured. Based on these results, learning materials was developed according to their needs. After the learning activities in one semester, the researcher collected feedback from students regarding online learning satisfaction using sentiment text analysis.

IntenCheck [24] was used to analyze the feedback data after learning using Wizer.me and Socrative. This instrument measures the text based on six psycholinguistic categories: attitude, emotions, insincerity, communication style, timeline, and motivation. The participant of this research was forty-four students. The value of this analysis was $0-100$. The score for attitude shows 100 , which shows that the students provide positive feedback about the usage of Wizer.me and Socrative.

\section{RESULTS}

\subsection{Experiment purpose}

The teacher experimented at the beginning of the semester to rate how my students perceive to use the digital worksheet in the classroom, do the students aware of Wizer.me software and Socrative application. This survey was conducted to understand the learners, which could help me design appropriate teaching and learning materials. The results in Figure 1 show that $72.7 \%$ of students like to use interactive worksheets in their classes. These findings are no surprise and represent worldwide research on the profile and the natural affinities between a typical university student and mobile technology [20], [25].

Another result in Figure 2 indicated that $88.6 \%$ of students answered they do not know about Wizer.me software. It was an opportunity for me to introduce a tool that they did not know before. Besides, 93.2\% of students mentioned that they did not know about the Socrative application. This also excites me to introduce another tool that my students did not know before.

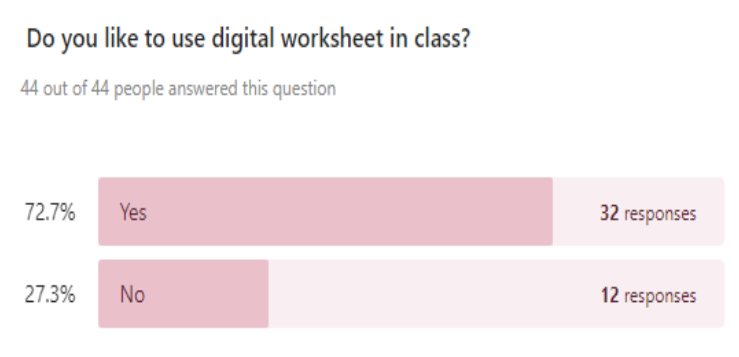

Figure 1. Digital worksheet usage
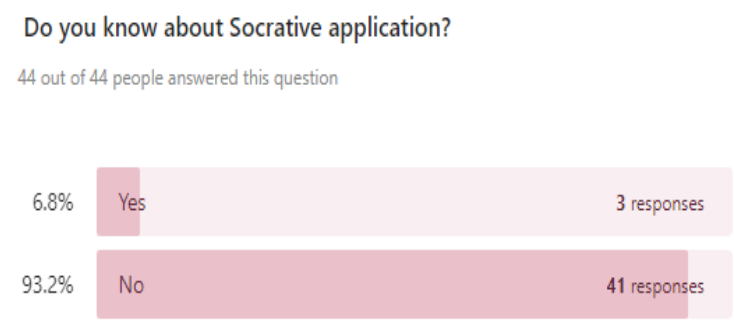

Figure 2. Wizer.me knowledge

After this information was found, the teacher started using Wizer.me and Socrative application in the teaching and learning process. As mentioned before, the slides were uploaded in the online learning platform and requested students to answer the questions which is created using Wizer.me before starting the class. Their answers were checked by the teacher and did the discussion and explanation in class after the 
teacher explained the lesson. Once, the lesson is completed, and then students were requested to answer the questions that were created using Socrative application. This exercise is to ensure the students understand the lesson. The teacher did the same method to teach all the eight topics in CCM for that semester.

At the end of the semester, the teacher asked the students: "Do you like my teaching and learning method; Anything that I should change?" The teacher received a total of 44 responses as shown in Figure 3, and it is attached a few answers from the students.

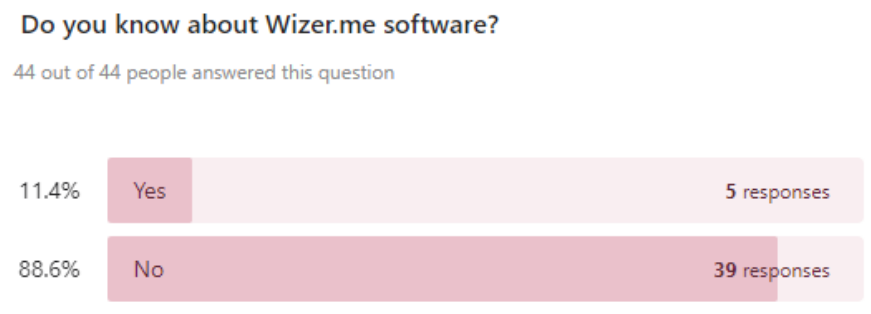

Figure 3. Socrative application knowledge

I really enjoy in your class and your lectures are easier to understand. (Student 1)

Yes. I like. Nothing to change because you have what I am searching for. How you communicate with students, help the students. Not all of lecturer use the same method as you do. Thank you for teaching me. (Student 2)

Yes, I like your teaching style Dr. It is more comfortable and convenient. Dr had taught us with your own style and excellent presentation. I have enjoyed in your class. Usually, I used to play phone in class if I get boring. However, in this class so far, I listen to your lectures and not get bored because I can get full mark in Wizer.me/Socrative at the end of the class. (Student 3)

Overall, I like a lot how Dr. Narentheren teaches his student. His teaching style is unique. For example, he keeps giving gestures and movement while lecturing, also Dr. Narentheren always uses Wizer.me or Socrative for doing assignment or quiz, it is a unique way to teach the student. (Student 4)

Yes. Overall, I really like your teaching method because you conduct the class in two-way communication likes you always try to communicate with the students. In addition, of course the way you deliver the message is easy to understand by only using the main key instead of reading the long sentence from the slides. I never get bored or sleepy during class. (Student 5) Yes, I do! Because it makes me more interested when learn in class. It has built something new and attractive when learning the subject. I also hope this Wizer.me can be use in another subject too. (Student 6)

\subsection{Sentiment analysis}

In order to understand the real meaning from the students' feedback, we performed sentiment text analysis using IntenCheck sentiment text analysis software [24]. This IntenCheck software measures the text based on six psycholinguistic categories: attitude, emotions, insincerity, communication style, timeline, and motivation. We inserted the forty-four students' feedback on using Wizer.me and Socrative application in IntenCheck software and ran the analysis. The figures show the findings from the IntenCheck software based on corresponding value on $0-100$.

The score for attitude in Figure 4 shows 100, which shows that the students provide positive feedback about the usage of Wizer.me and Socrative. This is based on students' feedbacks, where they mentioned several words such as simple, engaging, easy, fun, enjoyable, effective, and convenient. Next, the score for emotions in Figure 5 shows that 92 on joy. That means the students feedback shows that they are happy using this Wizer.me and Socrative. Several words in their feedback justified the joy such as enjoy, good, comfortable, excellent, appreciate and wonderful. 


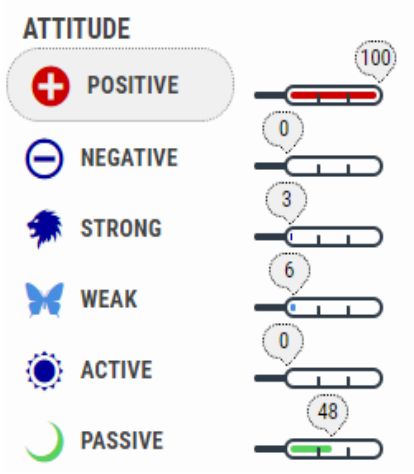

Figure 4. Attitude after completed Wizer.me and Socrative

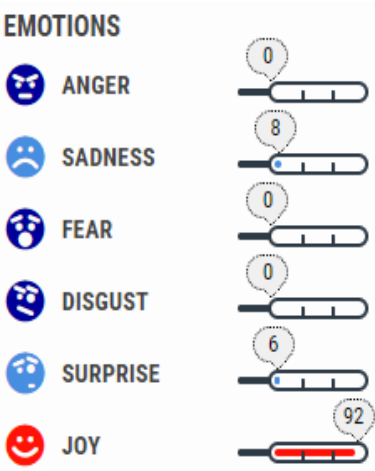

Figure 5. Emotions after completed Wizer.me and Socrative

The insincerity score in Figure 6 illustrated whether the students are truthful or lying. The score shows 2 for insincerity, which means the feedbacks given by students, are truthful and they are sincere and honest. They used words such as usually, so far and ever which shows that truthfulness and genuineness. Next the score for the communication style in Figure 7 is 100 for rational. This shows that the language used by the students in their feedback reflected logical thinking and thoughts. Students used words such as understand, unique, teaching, method reflect the rational communication style.

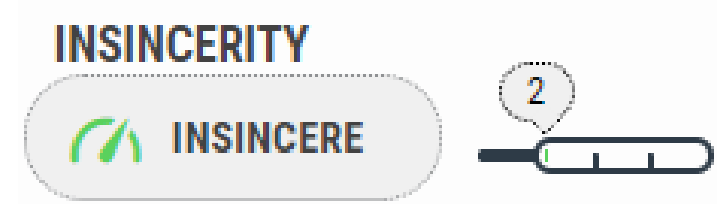

Figure 6. Insecurity after completed Wizer.me and Socrative

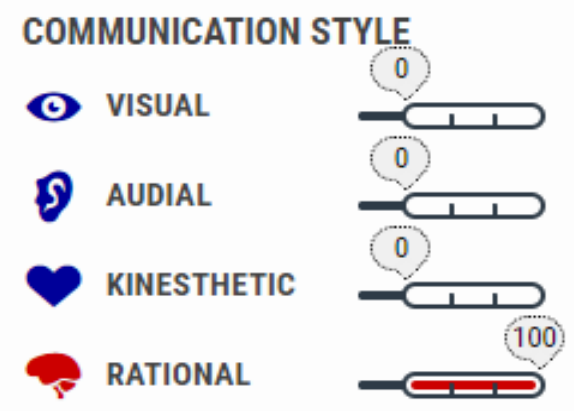

Figure 7. Communication after completed Wizer.me and Socrative

The timeline score in Figure 8 shows 50 for future. This shows that the students tend to think more about the future. For example, they used words such as anticipate, will, expect which reflecting the future. Lastly, the score for the motivation in Figure 9 shows 95 on toward. This shows that the students expressed the feedback by moving towards what is desired or wanted. They used several words such as convenient, forward, perfect, and next. 
TIMELINE
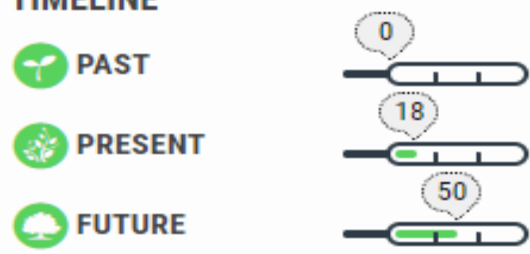

Figure 8. Timeline after completed Wizer.me and Socrative
MOTIVATION

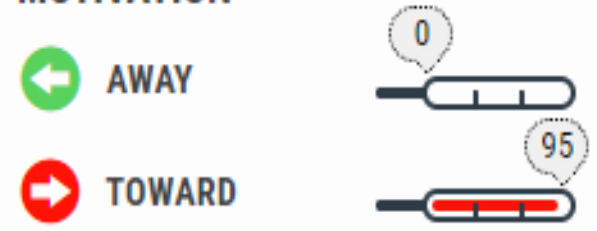

Figure 9. Motivation after completed Wizer.me and Socrative

Overall, students showed positive attitude and remained emotionally joyous as shown in Table 1. Furthermore, students also displayed sincerity along with rational communication. Besides, when they used future tense and displayed high motivation, it clearly showed how much they anticipated the lessons. Thus, it can be said that using Wizer.me and Socrative application is highly recommended method for technology enabled teaching and learning.

Table 1. Summary of sentiment analysis

\begin{tabular}{ccc}
\hline Psycholinguistic categories & Elements & Score (100) \\
\hline Attitude & Positive & 100 \\
Emotion & Joy & 92 \\
Insincerity & Insincere & 2 \\
Communication & Rational & 100 \\
Time & Future & 50 \\
Motivation & Toward & 95 \\
\hline
\end{tabular}

\section{DISCUSSION}

In this study, the teacher used social learning theory (SLT) with technology enabled learning. SLT offers a valuable context for considering how students learn by observational learning [26]. SLT is about learning by observation and cognitive processes in a social setting where learners internalize and understand what they see to mimic behavior. SLT suggested that the four different steps such as attention, retention, reproduction, and motivation. The first step is the students' emphasis on the actions. They need to see what actions they want to replicate or to reproduce other people. Secondly, you must internalize and hold what you saw. This means that a student proves the behavior or acts it is to imitate psychologically. This includes cognitive processes. Third, the insight acquired from attention and retention processes requires the ability to replicate actions in practice. Finally, students must be inspired to practice or imitate their actions [27]-[29]. In this study, the teacher wanted to explain to what extent the SLT could incorporate Wizer.me and Socrative application as innovative teaching methods.

\subsection{Attention}

The teacher has used a flipped classroom pedagogical approach, which gives the students basic concepts for pre-class learning to allow the time of class to implement and expand on these fundamental concepts. During the digital age, learners can access more content independently than ever, making learning and knowledge placement central to the creation of learning outcomes. By integrating the strengths of computerized learning with face-to-face class time, a tilted classroom can effectively enhance student performance, increase student participation, and improve the development of critical thinking [30]. The teacher gave the notes for CCM and requested the students to read the materials and answer the discussion questions posted in Wizer.me software as in Figure 10. During class time, most of the time will be spent in discussion and problem-solving activities as shown in Figure 11. These activities will allow the instructor to be a facilitator or mentor. 


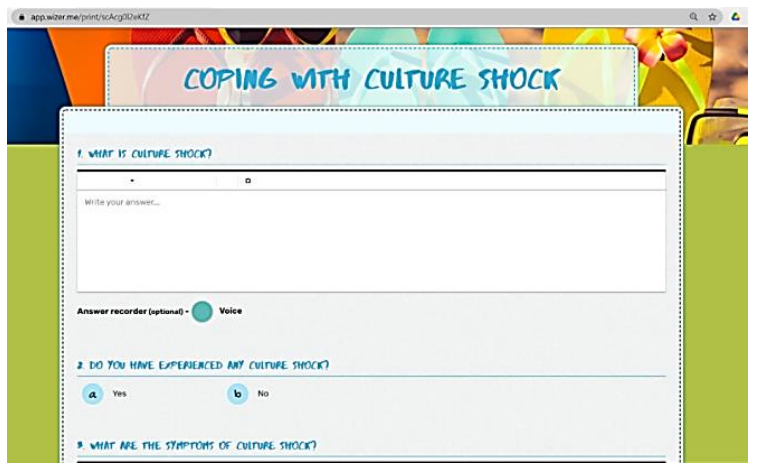

Figure 10. Sample Wizer.me activity

\section{CLASSROOM TEACHING \& LEARNING}

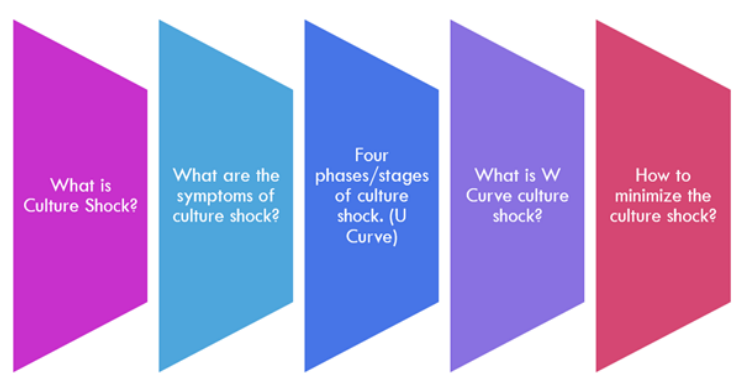

Figure 11. Classroom teaching and learning discussion

\subsection{Retention}

It is crucial for students to remember what they learned. In order to ensure they understood the critical information from the teaching and learning process, the teacher always makes a reflection or wrap up session. This will help recall whatever things the students learnt in the classroom as shown in Figure 12.

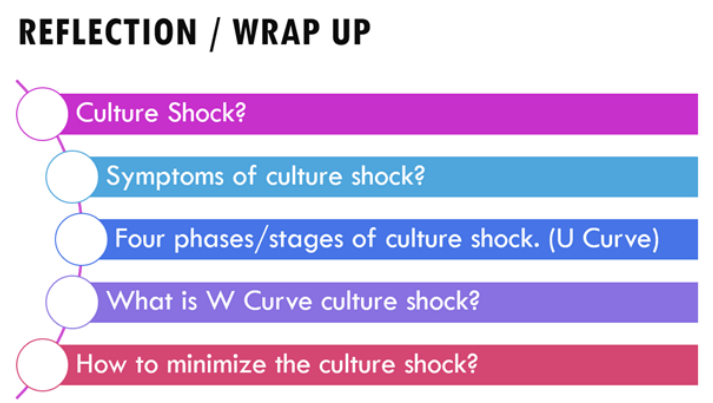

Figure 12. Reflection/Wrap up session

\subsection{Reproduction}

The reproduction step relies heavily on attention and retention phases. The students must figure out what they have learned since completing the two steps above. The teacher provided opportunities for practical applications using Socrative application to enable students to develop their knowledge and skills. For example, in Figure 13, the teacher has given questions with multiple choices, true or false questions, as well as open-ended questions in the Socrative application. This activity will enhance their knowledge which in lines with proverb 'practice makes perfect'.

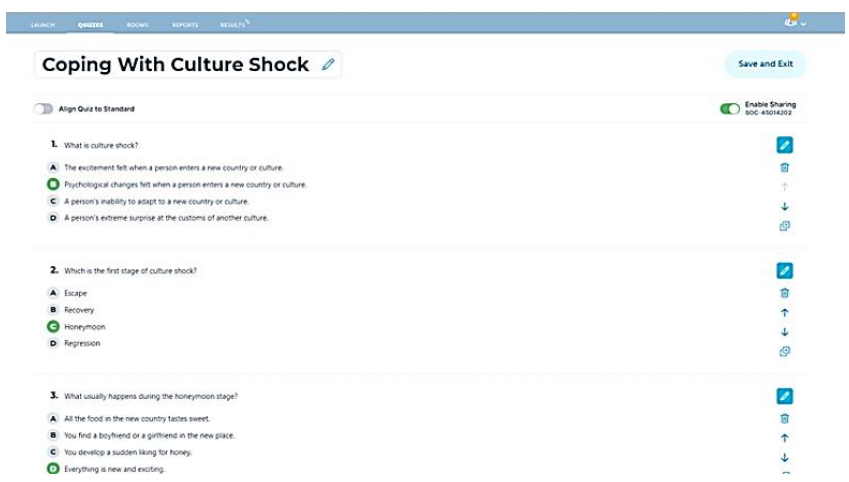

Figure 13. Socrative questions 


\subsection{Motivation}

We must be inspired to do something. Besides, the teacher also used the Socrative application for evaluation purposes to improve the student's motivation [31], [32]. After the replies, the teacher received an excellent report showing answers for each question from each student. Socrative also provides statistics in real-time about how many students responded, what they replied to and the percentages of correct and incorrect responses as well as shows the wrong answers appear in red and correct ones in green as given in Figure 14. The teacher can spot difficulties among students at a single glance and provide students with immediate formative feedback. Drawing from this experience, the teacher fully agreed that Socrative application increases students' motivation. The SLT and technology-enabled learning work well together [33]-[36]. The lecturers need to ensure the content, collaboration, and communication in line with the digital technology they want to use in teaching and learning process [37]-[39].

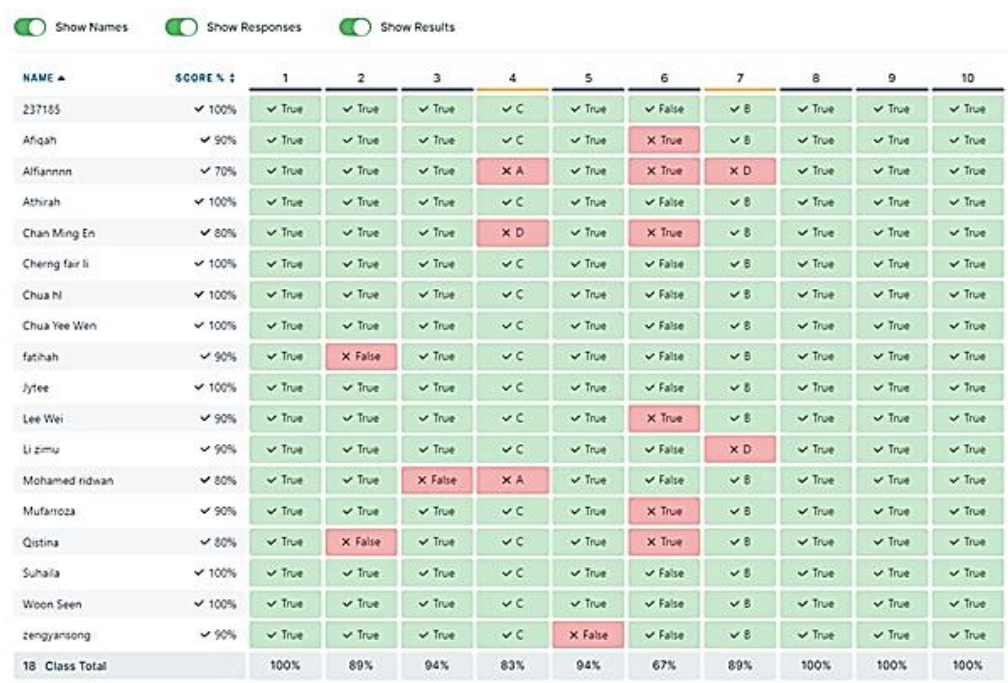

Figure 14. Socrative report

The digital worksheets interactive elements fully involve students when learning takes place. With a practical approach, technology draws students, encourages them to see the task, and understands the topic better. Digital worksheets often have elements that inspire and encourage students. Progress bars show them how much they have done, allowing them to assess and work through deadlines. Teaching materials play an essential role in successful education and learning, and suitable teaching materials provide students with more continuous learning, attract interest, and clarify vague concepts [40]-[42].

Technology has shifted the way that instructors teach students in higher education [43], [44]. Quality of education depends on the method of teaching adopted by the teachers in the classroom. In this hyper technologized society, learners are demanding integrating ICT use in the classroom. Embedding digital pedagogy in teaching and learning is urgently needed to help the educators and students appreciate the role of technology in teaching pedagogy and content knowledge (TPACK). Teaching accompanied by electronic tools is very relevant, and e-learning offers an opportunity for the student's learning process to be successful. The SLT and technology-enabled learning work well together. This study also shown that the social learning theory could incorporated Wizer.me and Socrative application as innovative teaching methods.

During this COVID-19 pandemic, there is a rising need to adopt digital technology to the education ecosystem. In education, digital transformation will strengthen the conventional face-to-face learning environment. Educators should build pedagogical models to align them with students better. Growing numbers of digital assets have changed the requirements of modern learners as a result of this pandemic. Educational institutions need new models of education to be established in order to counter the situation. Lecturers should always seek opportunities to learn beyond the traditional classroom approach.

Indeed, as a digital teaching tool, most students have positive views on Wizer.me and Socrative. The use of resources such as Wizer.me and Socrative application improved involvement and interaction in the classroom, contributing to increasing class engagement. Also, it offered immediate input on what students know, which is beneficial for teachers, as teachers can then adjust and reinforce those concepts in future classes. 


\section{CONCLUSION}

Measuring student perception and awareness in learning applications (i.e., Wizer.me, and Socrative) is a reasonable basis for planning learning. In this study, a digital worksheet integrated with Wixer.me and Socrative application was used. Intensive interaction using these two applications impacts increasing the level of learning engagement and the level of understanding of the subject matter. The results of processing student feedback data collected with IntenCheck explained that learning went well positively on attention, retention, reproduction, and motivation aspects. Thus, the learning strategy developed can provide solutions to positive students' involvement in online learning. Wizer.me and Socrative application are considered to be valuable tool to understand and assimilate concepts. It has enabled them to be entertainingly conscious of their expertise. To make innovative teaching methods, teachers/lecturers could use Wizer.me and Socrative application in their teaching and learning process.

\section{ACKNOWLEDGEMENTS}

This research was funded by Universiti Teaching and Learning Centre (UTLC), Universiti Utara Malaysia under the Scholarship of Teaching \& learning (SoTL) grant.

\section{REFERENCES}

[1] R. Sani, "Mission ahead: Future-proofing education," New Straits Times, 2020. [Online]. Available: https://www.nst.com.my/education/2020/01/552528/mission-ahead-future-proofing-education.

[2] E. Komara, "The Challenges of Higher Education Institutions in Facing the Industrial Revolution 4.0," HONAI: International Journal for Educational, Social, Political \& Cultural Studies, vol. 3, no. 1, pp. 15-26, 2020.

[3] T. Ahmad, "Preparing for the future of higher education," On the Horizon, vol. 23, no. 4, pp. 323-330, 2015.

[4] M. Weller and T. Anderson, "Digital resilience in higher education," European Journal of Open, Distance and eLearning, vol. 16, no. 1, pp. 53-66, 2013.

[5] L. García-Pérez, M. García-Garnica, and E. M. Olmedo-Moreno, "Skills for a Working Future: How to Bring about Professional Success from the Educational Setting," Education Sciences, vol. 11, no. 1, pp. 1-25, 2021, doi: 10.3390/educsci11010027.

[6] G. Hauser and R. Hauser, "Pedagogy, practice and teaching innovation at Harvard," Harvard Magazine, 2011. [Online]. Available: http://harvardmagazine.com/2011/10/analysis-pedagogy-practice-and-teaching-innovation-atharvard.

[7] A. Mróz and I. Ocetkiewicz, "Creativity for sustainability: How do polish teachers develop students' creativity competence? Analysis of research results," Sustainability, vol. 13, no. 2, pp. 1-20, 2021, doi: 10.3390/su13020571.

[8] Y. A. Lee, "Case study on the effect of teaching innovation on learning effectiveness: using a moderator of integrating information technology into teaching," Journal of Human Resources and Adult Learning, vol. 7, no. 1, pp. 34-49, 2011

[9] K. Smith, "Cultivating innovative learning and teaching cultures: a question of garden design," Teaching in Higher Education, vol. 16, no. 4, pp. 427-438, 2011.

[10] C. Zhu, "How innovative are schools in teaching and learning? A case study in Beijing and Hong Kong," AsiaPacific Education Researcher, vol. 22, no. 2, pp. 137-145, 2013.

[11] N. Kaliappen, "Educational Benefits of Using Business Strategy Game (BSG) in Teaching and Learning Strategic Management," International Journal of Emerging Technologies in Learning, vol. 14, no. 7, pp. 209-215, 2019.

[12] C. Zhu, D. Wang, Y. Cai, and N. Engels, "What core competencies are related to teachers' innovative teaching?" Asia-Pacific Journal of Teacher Education, vol. 41, no. 1, pp. 9-27, 2013.

[13] T. M. Wong, "Teaching innovations in Asian higher education: perspectives of educators," Asian Association of Open Universities Journal, vol. 13, no. 2, pp. 179-190, 2018.

[14] D. W. Brooks, Web-teaching: A guide to designing interactive teaching for the World Wide Web. Springer Netherlands, 2001.

[15] J. Keengwe, G. Onchwari, and J. OnChwari, "Technology and student learning: Towards a learner centered teaching model," AACE Journal, vol. 17, no. 1, pp. 11-22, 2009.

[16] G. Lowerison, J. Sclater, R. F. Schmid, and P. C. Abrami, "Are We Using Technology for Learning?" Journal of Educational Technology Systems, vol. 34, no. 4, pp. 401-425, 2006, doi: 10.2190/ER58-3H7P-Y8FK-U8F7.

[17] Wizer.me, About us, 2020. [Online]. Available: https://app.wizer.me/about-us.

[18] Socrative, About Socrative, 2020. [Online]. Available: https://socrative.com.

[19] S. Pryke, "The Use of Socrative in University Social Science Teaching," Learning and Teaching, vol. 13, no. 1, pp. 67-86, 2020.

[20] T. Ahmad, "Mobile phones as a learning tool: a lecturer's viewpoint," Society and Business Review, vol. 13, no. 2, pp. 132-139, 2018.

[21] P. Mishra and M. Koehler, "Technological pedagogical content knowledge: A framework for teacher knowledge," Teachers College Record, vol. 108, no. 6, pp. 1017-1054, 2006.

[22] M.J. Koehler, P. Mishra, and W. Cain, "What is technological pedagogical content knowledge (TPACK)?" Journal of Education, vol. 193, no. 3, pp. 13-19, 2013. 
[23] J. Guggemos and S. Seufert, "Teaching with and teaching about technology - Evidence for professional development of in-service teachers," Computers in Human Behavior, vol. 115, Feb. 2021, doi: 10.1016/j.chb.2020.106613.

[24] IntenCheck, About us, 2020. [Online]. Available: http://intencheck.com/.

[25] S. Kurkovsky, "Mobile game development: improving student engagement and motivation in introductory computing courses," Computer Science Education, vol. 23, no. 2, pp. 138-157, 2013.

[26] A. Bandura and D. C. McClelland, Social learning theory (Vol. 1). Prentice Hall: Englewood cliffs, 1977.

[27] J. Horsburgh and K. Ippolito, "A skill to be worked at: using social learning theory to explore the process of learning from role models in clinical settings," BMC Med Educ., vol. 18, article no. 156, pp. 1-8, 2018, doi: 10.1186/s12909-018-1251-x.

[28] J. R. Hill, L. Song, and R. E. West, "Social learning theory and Web-based Learning environments: A review of research and discussion of implications," American Journal of Distance Education, vol. 23, no. 2, pp. 88-103, 2009, doi: 10.1080/08923640902857713.

[29] S. Kurt, "Social learning Theory: Albert Bandura," Educational Technology, 2020. [Online]. Available: https://educationaltechnology.net/social-learning-theory-albert-bandura.

[30] S. Ghavifekr and W.A.W. Rosdy, "Teaching and learning with technology: Effectiveness of ICT integration in schools," International Journal of Research in Education and Science (IJRES), vol. 1, no. 2, pp. 175-191, 2015.

[31] F. F. Cerqueiro and A. Martín-Macho Harrison, "Socrative in higher education: Game vs. other uses," Multimodal Technologies and Interaction, vol. 3, no. 3, pp. 1-19, 2019, doi: 10.3390/mti3030049.

[32] C. Tu, "On-line learning migration: From social learning theory to social presence theory in a CMC environment," Journal of Network and Computer Applications, vol. 23, no. 1, pp. 27-37, 2000, doi: 10.1006/jnca.1999.0099.

[33] R. McCormick, "Issues of learning and knowledge in technology education," International Journal of Technology and Design Education, vol. 14, no. 1, pp. 21-44, 2004, doi: 10.1023/B:ITDE.0000007359.81781.7c.

[34] A. Kassabolat, S. Kadirsizova, M. Kozybayeva, K. Kalkeyeva, M. Zhorokpayeva, and Y. Aknur, "Future Teachers' Opinions on Preparation and Use of Interactive Materials in Teaching," International Journal of Emerging Technologies in Learning, vol. 15, no. 23, pp. 121-130, 2020.

[35] N. Hativa, Teaching for Effective Learning in Higher Education. Dordrecht: Kluwer Academic Publishers, 2001.

[36] A. Clark-Wilson, O. Robutti, and M. Thomas, "Teaching with digital technology," ZDM Mathematics Education, vol. 52, pp. 1223-1242, 2020, 10.1007/s11858-020-01196-0.

[37] I. González-González, C. Alcaide-Muñoz, and A.I. Jimenez-Zarco, "Using Socrative App for Accounting Students in Higher Education," A. Misseyanni, M.D. Lytras, P. Papadopoulou, and C. Marouli, Ed., Active Learning Strategies in Higher Education. Emerald Publishing Limited, 2018, pp. 293-313.

[38] K. Borawska-Kalbarczyk, "Digital World of Excess - Pedagogical Reflections on Students and Education Immersed in New Technologies," International Journal of Pedagogy, Innovation and New Technologies, vol. 7, no. 1, pp. 2-10, 2020, doi: 10.5604/01.3001.0014.4452

[39] I. Talysheva, K. Pegova, and L. Khaliullina, "The Use of Electronic Educational Resources of The University as A Means of Increasing the Educational Motivation of Students," International Journal of Emerging Technologies in Learning, vol. 16, no. 1, pp. 289-304, 2021.

[40] N.O. Argawati and L. Suryani, "Digital-based instruction: Chances and challenges in English language teaching context," International Journal of Evaluation and Research in Education (IJERE), vol. 9, no. 4, pp. 1138-1144, 2020.

[41] S. Krishnamurthy, "The future of business education: A commentary in the shadow of the Covid-19 pandemic," Journal of Business Research, vol. 117, pp. 1-5, 2020, doi: 10.1016/j.jbusres.2020.05.034

[42] J. Zimmerman, "Coronavirus and the great online-learning experiment: Let's determine what our students actually learn online," The Chronicle of Higher Education, Mar. 2020. [Online]. Available: https://www.chronicle.com/article/Coronavirusthe-Great/248216.

[43] L. S. Neuwirth, S. Jović, and B. R. Mukherji, "Reimagining higher education during and post-COVID-19: Challenges and opportunities," Journal of Adult and Continuing Education, pp. 1-16, 2020, doi: $10.1177 / 1477971420947738$

[44] S. Ashour, "How technology has shaped university students' perceptions and expectations around higher education: An exploratory study of the United Arab Emirates," Studies in Higher Education, vol. 45, no. 12, pp. 2513-2525, 2019, doi: 10.1080/03075079.2019.1617683. 